原著

順天堂医学 $37(2)$

P. 208 217 (1991)

$$
\text { トランスジェニックマウスの胸腺における }
$$

\section{ユニークな導入Thy-1.1 遺伝子の発現様式}

\title{
Expression pattern of Thy-1.1 antigen in transgenic mice
}

淡路 正則*1) 斎藤十 - 7 1) 野沢慎吾*2)

Masanori AW Ji, M. D. Ju-ichi Saitoh, M. D. Shingo NOZAWA, M. D.

阿部雅明*2) 西村裕之*2)

Masaaki ABE, Ph. D. \& Hiroyrizi NiShimuRA, Ph. D.

マウスの胸腺細胞・T細胞のマーカ一抗原である Thy-1 分子は, 正常では胸腺細胞と末梢 $\mathrm{T}$ 細 胞の全てに発現されている. ての Thy-1 抗原を codeする遺伝子には Thy-1.1 と Thy-1.2 とい う 2 つ allotype が存在するが, 今回われわれは Thy-1.2 マウスの受清卵に Thy-1.1 遺伝子 を transgeneし, その発現様式を調べてみた。その結果, 内在性 Thy-1 (Thy-1.2) 分子は胸腺細 胞と末梢T細胞の両者に発現していたが, 導入 Thy-1.1 遺伝子の発現は, 胸腺細胞には認められ たが末梢T細胞には認められなかった. 乙れは導入した Thy-1.1 遺伝子 DNA が, 末梢T細胞で の発現を規定する cis-acting な調節配列を含まないため, 発現調節因子との相互作用が起てら ないためと考えられた。一方, 胸腺細胞における導入 Thy-1.1 遺伝子の発現を詳細に検討した 結果, 胸腺細胞の大半を占める未分化な $\mathrm{CD} \mathrm{3}{ }^{-} / \mathrm{T}$ cell receptor (TCR) - 細胞においては, 導入 した Thy-1.1 遺伝子の発現はほぼ全てにみられたが, 分化した TCR ${ }^{+} \mathrm{CD} 4{ }^{+}$または CD $8{ }^{+}$ single positive (SP) 胸腺細胞には, Thy-1.1 を表現するものと表現しないものの 2 つのグループ か認められた. てのてとから，すでに分化していると考元られていたSP胸腺細胞の中にも，末梢T細 胞へと移行する際洶腺内で導入された Thy-1.1 遺伝子が消失していくという, もう一つの分化過 程の存在する可能性が示唆された。一方, double negative (DN) 胸腺細胞においては, 全ての $\mathrm{CD} \mathrm{3}^{+} / \mathrm{TCR}^{+}$細胞は Thy-1.1- であった。乙れらの結果から, CD 3+ DN 細胞の成熟過程は, $\mathrm{CD} 3{ }^{+} \mathrm{SP}$ 細胞,とは異なっていると考元られた. 以上の結果から, 今回われわれが生産した Thy-1.1 トランスジェニックマウスは, 乙れまで知られていなかった CD 3 + 胸腺細胞の最終成熟過程におけ る細胞内の, 諸現象の解析に有用なモデルであると考えられた。

索引用 語: Thy-1.1, 胸腺細胞成熟, トランスジェニックマウス

Key words : Thy-1.1, thymocyte maturation, transgenic mouse.

\section{緒言}

Thy-1 は分子量 $25 \mathrm{kDa}$ ，ホスファチジルイノシ

* 1 ) 順天堂大学医学部産婦人科学講座

* 2) 順天堂大学医学部病理学第二講座

* 1 ) Department of Obstetrics and Gynecology, Juntendo University School of Medicine, Tokyo, Japan

* 2 ) Department of Pathology ( II ), Juntendo University School of Medicine, Tokyo, Japan.

[Oct. 22, 1990 原稿受領〕(Nov. 22, 1990 掲載決定)
トールを介して細胞膜に結合している膜蛋白質で ある ${ }^{1 !}$. その一次構造は, 免度グロブリンV領域の ドメイン類似の構造をもち, MHC (主要組織適合 性遺伝子複合体) の遺伝子産物, T細胞受容体（T CR）などを含む免疫グロブリン超遺伝子族の一 員であり,しかもその中で, 特に基本的・原始的 な構造を保持した分子と考えられている2!. Thy-1 がどのような機能を担っているかは未だ明らかで 
はない. 広い種において脳に多量に発現されてお り, シナプス形成の際何らかの認識機序に関わる ものと推測されている. Thy-1 は最初マウスの胸 腺におけるア口抗原として見いだされたものであ り, 89番目のア之ノ酸残基の Arg と $\ln$ の違い により Thy-1.1 と Thy-1.2 の 2 つの表現型を有 (2)314), マウスにおけるT細胞や胸腺細胞のマカーとして重要な指標となっている5).

T細胞は抗原受容体 (T細胞受容体 TCR) によっ て抗原を認識するが, 成熟したT細胞は MHC の class I 遺伝子産物を介して抗原を認識するもの (CD $8^{+}$T細胞), および class II 遺伝子産物を介し て抗原を認識するもの（CD $4{ }^{+}$T細胞）の主に 2 種類に大別される. 胸腺細胞は CD $4 \cdot \mathrm{CD} 8$ の発 現について, double negative (DN) - double positive (DP), および CD 4 あるいは CD 8 single positive(SP) の細胞を含み, 大部分の胸腺細胞は $\mathrm{DN} \rightarrow \mathrm{DP} \rightarrow \mathrm{SP}$ の分化過程をとると考えられてい る.しかしながら, DN胸腺細胞の一 部は機能的に 成熟した性質を示すことが知られている. SP胸腺 細胞は, 従来表現型において成熟した $\mathrm{T}$ 細胞と同 様と考えられてきた。しかし, SP胸腺細胞から末 梢T細胞への分化過程があるのか, あるいはSP胸 腺細胞は, すでに末梢 $\mathrm{T}$ 細胞と同等の分化過程に 達しているのかに関しては未だ明らかになってい ない.

Thy-1 はマウスにおいては, 未だ胸腺における 分化過程にはいる以前の細胞 (pre-T細胞), DN ・ DP・SP 胸腺細胞および末梢T細胞に一貫して発 現している. Thy-1 の脳における発現は広い種に おいて共通しているが, リンパ系の細胞における 発現パターンは種によって異なっている ${ }^{6 / 7)}$. マウ スと異なりヒトでは, 大部分の胸腺および末梢 $\mathrm{T}$ 細胞にはThy-1抗原の発現は認められない8)9110). ラットでは胸腺細胞には発現するが, 未梢T細胞 には発現しない1112).

Thy-1 遺伝子の組織特異的発現調節の機構を探 る目的で, Gordon ら ${ }^{13)}$ は Thy-1.2 の遺伝子につ いてホモ接合体であるマウス受精卵の前核に, ヒ トThy-1 およびマウス Thy-1.1 遺伝子を導入
したトランスシェニックマウスを生産した．その 結果, 種による Thy-1 発現の組織特異性の違いは, Thy-1 遺伝子発現調節に係わる調節蛋白質 (transacting factor) の相違によるものではなく, Thy-1 遺伝子 DNA 上の近傍に存在する調節配列 (cisacting element）の違いに基づくものであるとと が示唆されている.てれらの Thy-1.1 トランスジェ ニックマウスにおいて明らかにされた重要な知見 のひとつは, 未梢T細胞において内在性 Thy-1.2 遺伝子が発現しているにもかかわらず, 導入マウ ス Thy-1.1 遺伝子産物が発現しなかったてとで ある。

本研究では, Thy-1.2 遺伝子の発現しているマ ウスに Thy-1.1 遺伝子を導入したトランスシェ ニックマウスを生産し, 導入遺伝子の胸腺細胞に おける発現様式を, 他の分化マーカーとの対比に おいて詳細に解析した. その結果, 導入した Thy1.1 遺伝子の発現は, $\mathrm{CD} 3^{+} / \mathrm{TCR} \alpha / \beta^{+} \mathrm{SP}$ 胸 腺細胞の $\mathrm{T}$ 細胞分化過程において, 細胞内の transacting なシグナルの変化を反映した指標として有 用な分化マーカーとなり得ることが示唆された。

\section{実験材料と実験方法}

\section{1. マウス}

受精卵採取のための交配用マウスとして, C57B $\mathrm{L} / 6$ (の゙) および (C57BL /6 X DBA /2) F 1 (B 6 D 2 F 1 ) (ㅇ), また偽妊娠代理母および里親用 の雌マウス, また偽妊娠マウス作製のための精管 結紮雄マウス用として ICR マウスを静岡実験動 物センターより購入した. 全てのマウスは14：10 （19時消灯 5 時点灯）の明暗サイクルで飼育した。 受精卵採取用に 6 8 週齢の雌マウスを用い, 過排 卵処置として46〜48時間の間隔で PMS および $\mathrm{H}$ CG (ともに帝国蔵器) 5 単位を腹腔内に注射した。 HCG 投与後すぐ雄マウスと交配し, 翌日胵栓の確 認されたマウスより採卵した. 偽妊娠用の雌マウ スも, 同日にあらかじめ精管結紮しておいた雄、 ウスと交配し, 翌日腟栓の確認されたマウスを卵 管内移植に用いた。 


\section{Thy-1.1 ゲノム DNA の調整}

マイクロインジョションに用いた Thy- 1.1 遺伝子 DNA は, Thy-1.1 遺伝子をもつ AKR / J マウスの胸腺リンパ腫, BW5147 細胞より調整し た遺伝子ライブラリーから単離した ${ }^{14) 15) 16}$. 低融点 アガロースゲルで EcoRI による8.2kbの遺伝子断 片を精製したのち, 受精卵の雄性前核に注入し た ${ }^{13)}$. これらの操作は, Leitz 社製のマイクロマニ ピュレーターおよびノマルスキー微分干渉装置付 き倒立顕微鏡を使用した.インジェクション後の 受精卵を偽妊娠マウスの卵管内一移植し, 腟栓確 認後20日目に仔マウスを得た. 自然分婏に至らな いマウスは分婏予定日当日に帝王切開にて仔マウ スを婏出し, 里親に哺育させた. 6 週齢に達した時 点で個体識別後, Thy-1.1 遺伝子が導入されたか どうかを調べるために尾の一部を切断して DNA を抽出し, サザンブロット法にて解析を行い, 外 来遺伝子の組み込まれたマウスを初代トランスシェ ニックマウスとした. その後トランスジェニック 系を樹立するために，そのマウスを C57BL / 6 マ ウスへ 6 回退交配し, 出生した仔マウス (F 6 ) が 6 週齢になった時点で解析に用いた。

\section{3.フローサイトメトリー}

Two-color analysis は FACStar (Becton Dickinson Mountain View CA) を, three-color analysisはFACScanまたはFACStar-plus（Becton Dickinson）を用いて行った。 細胞染色用のモノク ローナル抗体としては, Thy-1.1（NEI-002 NEN Research Products Boston MA), Thy-1.2 (30-H 12), $\mathrm{CD} 3(2 \mathrm{C} 11)^{\left.17)^{18}\right)}$, T細胞分化抗原のひとつ である CD 4 (Ly-11 GK1.5) や CD 8 (Ly-2/536.7), T細胞受容体のひとつである TCR $\alpha / \beta$ $(\mathrm{H} 57-597)^{19)}$ や TCR $\gamma / \delta(3 \mathrm{~A} 10)^{20)}$ 亿対する 抗体を用いた。細胞はまず FITC ラベル, Phycoerythrin (PE) ラベル, およびビオチン化したモ ノクローナル抗体とともにインキュベーションし, 次いで streptavidin-allophycocyanin (APC) (Becton Dickinson) で標識した. 死滅した細胞を染 色するために, てれらの細胞を $2 \mu g / m l 7 \mathrm{AAD}$ (Sigma Chemical Co., St. Louis MO) および10
\%FCS を含む培養液に再懸濁した。

4. 胸腺 single positive (SP) 細胞の調製

$\mathrm{CD} 4^{+}$またはCD $8^{+} \mathrm{SP}$ 胸腺細胞の調整では, ま ず最初にウサギ補体の存在下に各々抗 CD 8, また は抗 CD 4 モノクローナル抗体による細胞障害処 理を行い, 次いで抗ラットIgGヒツジ抗体 (Dynal Skoyen Norway) の結合したマグネティックビー ズを用いて,モノクローナル抗体の結合した残存 細胞を除去した ${ }^{21}$. それぞれの分画に残った double negative (DN) 細胞は, three-color 解析によっ てゲートアウトした.

5 . 胸腺 double negative (DN) 細胞の調製

胸腺DN細胞はまず補体, 抗 CD 4 および抗 CD 8 モノクローナル抗体を用いた細胞障害処理によっ て分離し, 次いで抗ラット IgG ヒツシ抗体の結合 したマグネティックビーズを用いて，残存の $\mathrm{CD} 4^{+} \mathrm{CD} 8^{+}$細胞を除去することにより単離した。 細胞の純度は, FITC でラベルした抗ラット Ig אマウスモノクローナル抗体（M-21 ヤマサ醬 油）で細胞を染めることにより検定し，常に98\% 以上の純度を得た。

結果

1. 胸腺細胞における導入 Thy-1.1 遺伝子の発現 様式

Thy-1.1 遺伝子の導入された 6 週齢のトランス シェニックマウス（F 6) の胸腺および脾臓を用い て, 導入 Thy-1.1 と内在性 Thy-1.2 の発現を twocolor 解析によって調べた. Fig.-1a のように, 導 入 Thy-1.1 遺伝子の発現は脾臓T細胞には認めら れなかった。胸腺細胞においては, 内在性の Thy1.2 は殆ど全ての胸腺細胞に発現していたが, 導 入された Thy-1.1 の発現は胸腺細胞の約 $88 \% に$ 限られていた (Fig.-1b). 対照として, Thy-1.1と Thy-1.2 の対立遺伝子についてへテロ接合体であ る (AKR X C57BL /6) F 1 マウスの胸腺細胞 に おける発現様式を調べたととろ, Thy1.1 ・Thy-1.2 ともに全ての細胞で同様の発現が 見られた (Fig.-1c). 

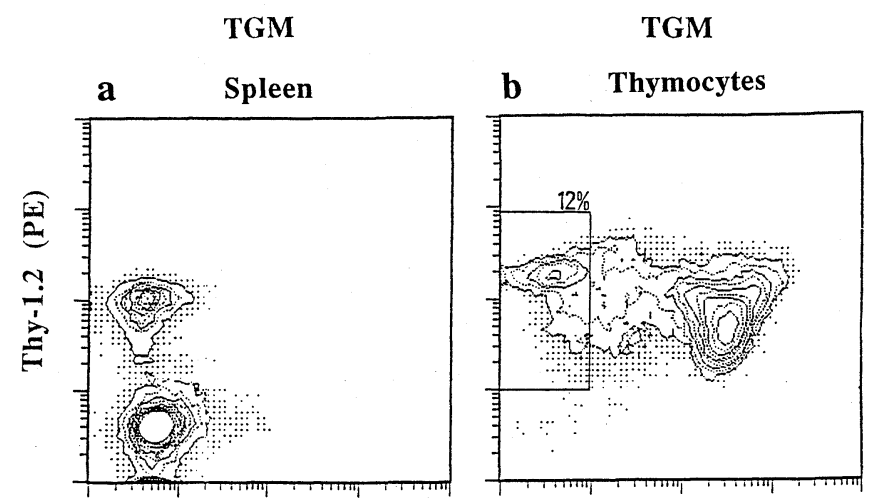

(AKR X C57BL/6) F1

Thy-1.1 (FITC)

Fig. -1 Dual-color flow cytometry analysis for Thy-1.1 vs. Thy-1.2 gene expressions of spleen cells (a) and thymocytes (b) between the 6-mo-old Thy-1.1 transgenic mouse and the (AKR X B6) F 1 mouse ( 6 -mo-old) heterozygous for Thy-1.1 and Thy-1.2 alleles(c). Note that in contrast to (AKR X B 6 ) F 1 mouse cells, all of the spleen T cells and 12\% of the thymocytes of transgenic mouse are negative for transgenic Thy-1.1 expression.

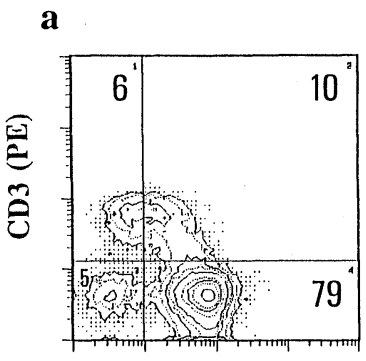

b

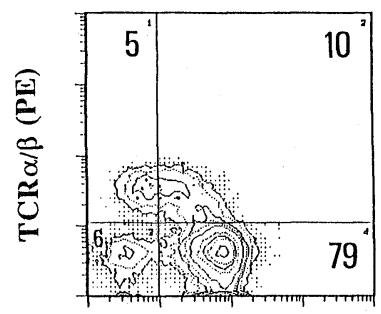

Thy-1.1 (FITC) c

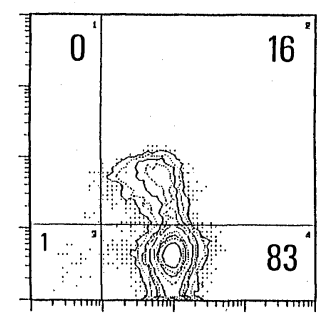

d

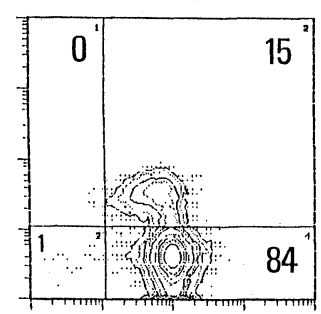

Thy-1.2 (FITC)

Fig. - 2 Dual-color flow cytometry analysis for the relation between $\mathrm{T}$ cell receptor $(\mathrm{CD} 3, \mathrm{a}$ and $\mathrm{c}$; TCR $\alpha / \beta, \mathrm{b}$ and $\mathrm{d}$ ) and Thy-1 expressions (transgenic Thy-1.1, a and b; endogenous Thy-1.2, c and $\mathrm{d}$ ) on thymocytes from a 6 -mo-old Thy-1.1 transgenic mouse. Numbers within the panels are percentages of cells.

Thy-1.1 トランスシェニックマウスの胸腺 細胞における Thy-1.1・Thy-1.2 と, CD 3 ・ TCR $\alpha / \beta$ との発現の相関を two-color 解 析によって調べた（Fig.-2). 殆ど全ての CD $3 / \mathrm{TCR} \alpha / \beta^{+}$胸腺細胞は Thy-1.2 陽性で あったが (Fig.- 2c,d), Thy-1.1 の発現につ いてみると, これらの細胞は陰性群と弱陽性 群に分かれた（Fig.-2a,b).

2. 胸腺 single positive (SP) 細胞における Thy-1.1の発現

殆ど全ての $\mathrm{CD} 4^{+}$または $\mathrm{CD} 8^{+}$胸腺SP細 胞に打いて, 内在性 Thy-1.2 の発現は陽性で あったが (Fig.- 3 e,f), 導入 Thy-1.1の発現 については, Thy-1.1+ と Thy-1.1-の 2 つの グループに均等に分けられた (Fig.- $3 \mathrm{a}, \mathrm{b}$ ). そこで CD 4, および $\mathrm{CD} 8^{+} \mathrm{SP}$ 胸腺細胞を各々 分離したのち, Thy-1.1 と TCR の発現様式 の相関を調べてみた。 その結果 Fig.- $4 \mathrm{a}, \mathrm{b}$ のように, CD $4^{+}$および $\mathrm{CD} 8^{+} \mathrm{SP}$ 分画双方 において, TCR $\alpha / \beta^{+}$胸腺細胞は Thy-1.1 陰性と陽性の 2 つの細胞亜集団からなってい た.なお, Thy-1.1+ と Thy-1.1-の 2つの集 団の中で, TCR $\alpha / \beta$ の発現量に差は認め 


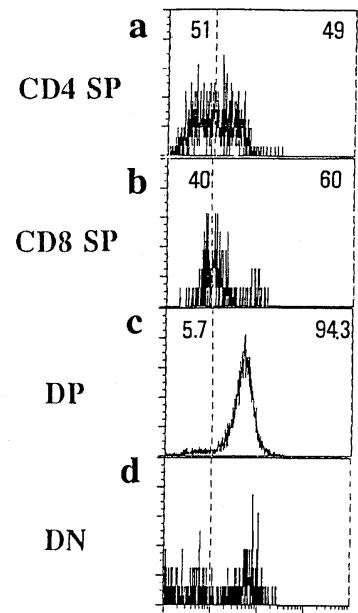

Thy-1.1

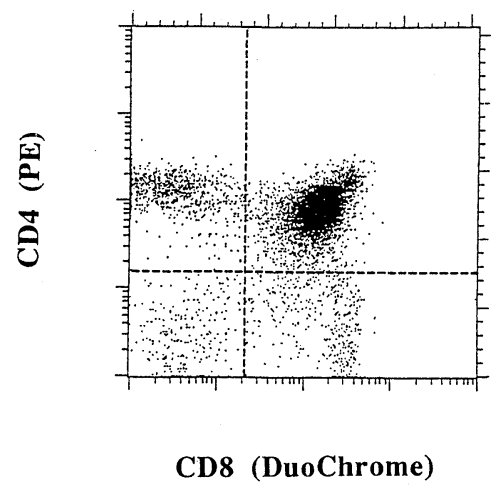

CD8 (DuoChrome)

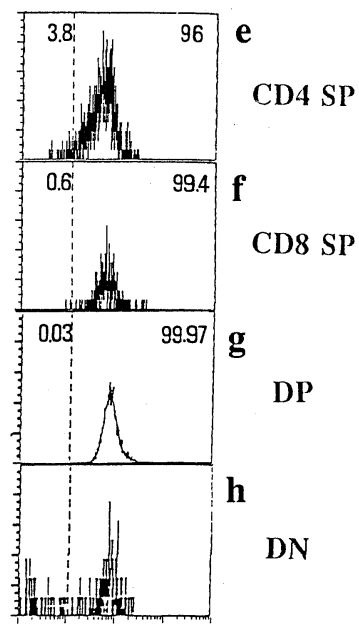

Thy-1.2

Fig. - 3 Three-color flow cytometry analysis for expressions of transgenic Thy-1.1 (a-d) vs. endogenous Thy-1.2 (e-h) in the CD $4{ }^{+} \mathrm{SP}(\mathrm{a}, \mathrm{e}), \mathrm{CD} 8^{+} \mathrm{SP}(\mathrm{b}, \mathrm{f}), \mathrm{DP}(\mathrm{c}, \mathrm{g})$ and $\mathrm{DN}(\mathrm{d}, \mathrm{h})$ thymocytes from the 6 mo-old Thy-1.1 transgenic mouse. Numbers within the panels are percentages of cells.
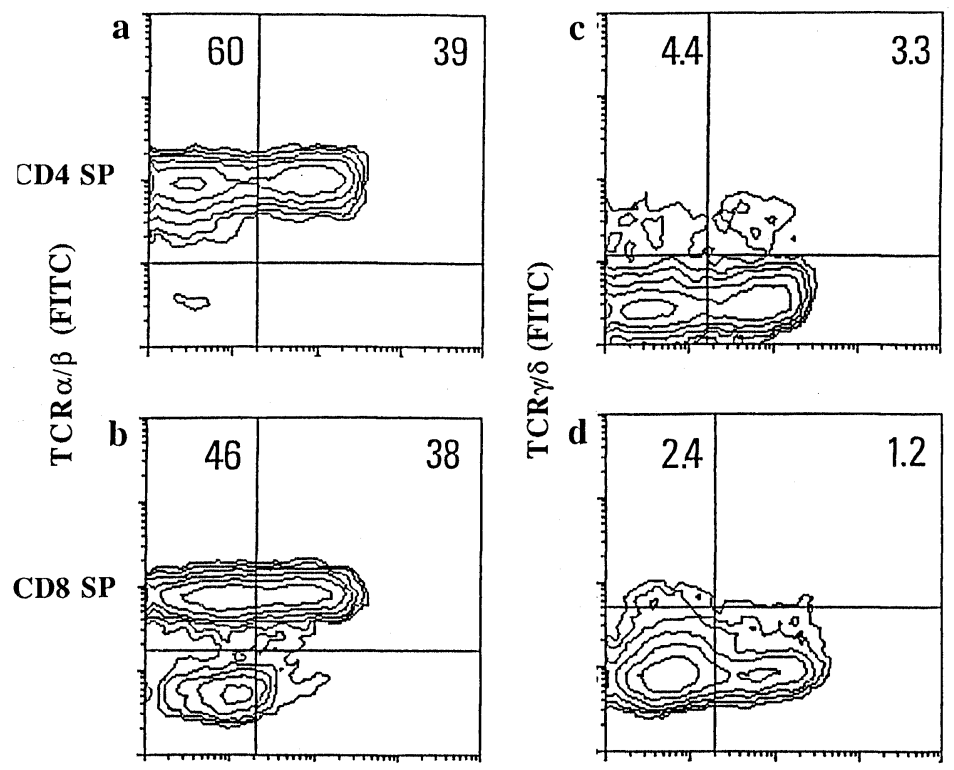

Thv-1.1 (DuoChrome)

Fig. - 4 Three-color flow cytometry analysis for expressions of transgenic Thy-1.1 vs. T cell receptors (TCR $\alpha / \beta$, a and b; TCR $\gamma / \delta$, $c$ and $d$ ) in each SP thy mocytes (CD $4{ }^{+}$SP, a and $c ; C D 8^{+}$SP, $b$ and d) from the 6 -mo-old Thy-1.1 transgenic mouse. Each $\mathrm{CD} 4^{+}$and $\mathrm{C}$ D $8{ }^{+}$SP thymocytes were isolated from DP thymocytes, as described in Materials and Methods. These SP thy mocytes were stained for CD 4 or CD 8 , Thy-1. 1 and TCR (TCR $\alpha / \beta$ or TCR $\gamma / \delta$ ) and subjected to the three-color flow cytometry analysis. Analysis were made after gating out the DN thymocytes. Numbers within the panels are percentages of cells. Note that either $\mathrm{CD} 4^{+}$or $\mathrm{CD} 8{ }^{+}$SP thymocytes are separated into two groups, one Thy $-1.1^{+}$and one Thy $-1.1^{-}$.

\section{られなかった。}

同様の結果が TCR $\gamma / \delta$ とThy1.1 との発現の関係の間にもみら れたが (Fig. $4 \mathrm{c}, \mathrm{d}$ ), CD $8+$ SP胸 腺細胞では, Thy-1.1+ よりも Thy$1.1^{-}$細胞に TCR $\gamma / \delta$ 発現量 が多い傾向があった（Fig.-4d).

3 . Double positive (DP) および double negative (DN) 胸腺細胞に おける Thy-1.1 の発現

大部分の $\mathrm{CD} 4{ }^{+} \mathrm{CD} 8+\mathrm{DP}$ 胸 腺細胞は Thy-1.1+ であったが, 少 ないながらも有意な量の $(5.7 \%)$ Thy-1.1- 細胞の存在が示された (Fig.- 3c). 乙の際, 内在性 Thy-1.2 は全てのDP胸腺細胞 $(99.97 \%)$ に 表現されていた（Fig.-3g）.

DN胸腺細胞における導入 Thy1.1 と内在性 Thy-1.20発現を two-color 解析によって調べた (Fig.- 5 ). その結果, DN胸腺細胞 は Thy-1.1 $1^{+} /$Thy $-1.2^{+} \cdot$ Thy-1.1 ${ }^{-}$ 


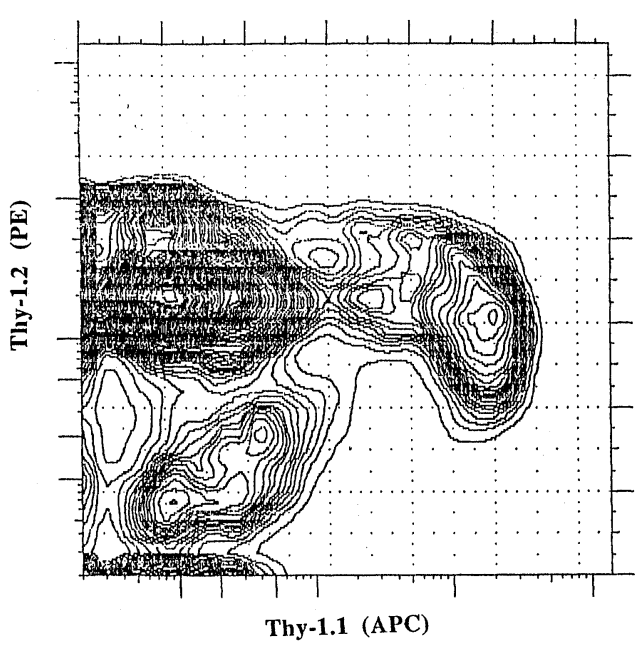

Fig. - 5 Dual-color flow cytometry analysis of transgenic Thy-1.1 vs. endogenous Thy-1.2 expression on DN thymocytes from the 6-mo-old Thy-1.1 transgenic mouse.

/Thy-1.2 - Thy-1.1- /Thy-1.2- の表現 型をもつ 3 つのサブセットに分かれ，その 割合は各々 $14.2 \% \cdot 67.8 \% \cdot 18.0 \%$ であっ た. Thy-1.1 $1^{+} /$Thy-1.2- 在示す細胞は見 られなかった。

DN胸腺細胞における導入 $\mathrm{Thy}-1.1$ と $\mathrm{T}$ $\mathrm{CR}$ との発現の関係を three-color 解析に よって調べた（Fig.-6）. DN胸腺細胞のう ち $\mathrm{CD} 3^{+}$(全DN胸腺細胞中 $10.3 \%$ ) のも のは全てThy-1.1-であったが, それらの細胞の うちのほほ80\%（全DN細胞中の7.9\%）は内在性 Thy-1.2+ であった（Fig.- $6 \mathrm{a}, \mathrm{b}$ ). このように $\mathrm{CD} 3^{+} \mathrm{DN}$ 胸腺細胞の大部分は, 未梢T細胞の表 現型である Thy-1.1- $/$ Thy-1.2 $2^{+}$を示した. なお, TCR $\alpha / \beta^{+} \mathrm{DN}$ 細胞について調べたところ, そ のほぼ半分 $(3.7 \%$ 中の $1.7 \%)$ が，またTCR $\gamma /$ $\delta^{+} \mathrm{DN}$ 細胞ではそのほほ全て (3.2\%中の2.9\%) が, Thy-1.1-/Thy-1.2 $2^{+}$であった (Fig.-6c〜f).

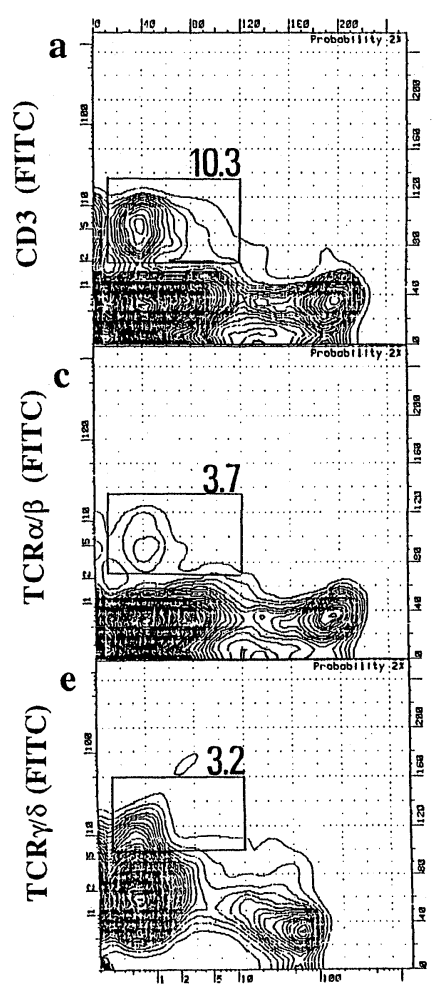

Thy-1.1 (APC)

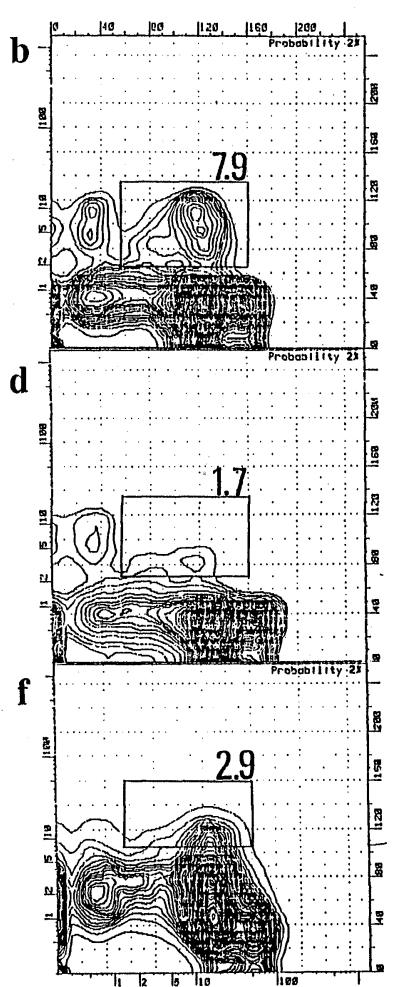

Thy-1.2 (PE)
Fig. - 6 Flow cytometry analysis for expressions of $T$ cell receptors (CD 3, TCR $\alpha / \beta$ and TCR $\gamma / \delta$ ), transgenic Thy-1.1 and endogenous Thy-1.2 on DN thymocytes from the 6 -moold Thy-1.1 transgenic mouse. Numbers within the panels are percentages of cells. Note that there is no population with the CD $3 / \mathrm{TCR}^{+}$Thy-1.1 $1^{+}$phenotype.

\section{考察}

Thy-1.2 マウスの受精卵に, Thy-1.1 遺伝子 D NA（EcoRI による8.2kb の DNA 断片）を導入 したトランスシェニックマウスの 1 系統を生産し, 導入 Thy-1.1 遺伝子の発現様式を調べた. その結 果, 導入 Thy-1.1 遺伝子の発現は胸腺細胞には認 められたが末梢 $\mathrm{T}$ 細胞には認められなかった。 Thy-1.1 トランスシェニックマウスに関し同様の 結果を他のグループも報告しているが(13)22(23)24), 今 回われわれが新しく得た発見の一つは, 胸腺細胞 中に抢いて DP 胸腺細胞の大部分は Thy-1.1 ${ }^{+}$ 
であったが，より分化した $\mathrm{CD} 4{ }^{+}$または $\mathrm{CD} 8{ }^{+} \mathrm{S}$ $\mathrm{P}$ 胸腺細胞中に Thy-1.1+, およよび Thy-1.1-の 2 つの亜集団が存在するという点である. 雨者間に おいて, 細胞表面の CD $3 / \mathrm{TCR}$ 複合体の発現量 に差は見られないので, この Thy-1.1+胸腺細胞 群は末梢T細胞と同様に, Thy-1.1- であるSP胸腺 細胞への分化過程にある細胞群と考えられる. 従 来から胸腺のSP細胞と，末梢T細胞とを識別する 良い手段がなかったので, 今回のこの発見は, T細 胞の最終的な成熟過程を研究するための良いモデ ルとなる可能性がある。

Thy-1 遺伝子発現の組織特異性における調節機 構は, ゲノム DNA 上に複数存在する cis-acting element（組織特異的プロモーター，エンハンサーな ど) と, trans-acting factor（遺伝子発現調節にか かわる蛋白質）との相互作用によって決定されて いると考えられるが, Gordon ら ${ }^{13}$ は, 種による発 現の組織特異性の相違は, Thy-1 遺伝子上の発現 の組織特異性の調節に関わっている cis-acting element の種による違いによるものであることを 示唆している. 最近 Vidal ら ${ }^{24}$ は, Thy-1 遺伝子 上の組織特異的な cis-acting regulatory element の分布を解析し, ゲノム DNA 上に散在する複数 の調節因子が独立に特定の組織での発現を規定し ていることを報告した. 今回われわれが生産した トランスジェニックマウスにおいて, 導入 Thy-1.1 遺伝子発現がSP胸腺細胞の一部と末梢T細胞で見 られなかったのは, 導入した Thy-1.1 ゲノム DN A クローンに末梢T細胞における発現を規定する cis-acting element が欠如していたためと考えら れる.

胸腺細胞成熟過程は，様々なT細胞系の機能に 係わる遺伝子とその発現を調節する複数の transacting factorによってプログラム・制御されて いるものと思われる ${ }^{25)}{ }^{26)}$. また胸腺細胞が末梢T細 胞へと成熟していく過程で, 細胞内のてれらのtransacting なシグナルに機能的・質的な変化があるも のと思われる ${ }^{27}$ 。細胞表面上にすでに機能的 CD 3 /TCR 複合体を形成しており，その意味では分化 しているといえるSP胸腺細胞にも，なお末梢
T細胞としての機能を獲得するためには，さらに 成熟過程を経る必要があると推定される，その過 程においてある種の trans-acting なシグナルに 質的な変化が要求され, その変化が導入 Thy-1.1 遺伝子の発現に反映されているものと考えられる.

DN胸腺細胞は, 導入 Thy-1.1 遺伝子および内 在性 Thy-1.2 遺伝子の発現に関して, Thy-1.1Thy-1.2- $2^{-}$Thy- $1.1^{-} /$Thy-1.2 $2^{+}$Thy-1.1 $1^{+} /$Thy$1.2^{+}$の 3 つのザセットに分けられた. Thy-1.1 /Thy-1.2- の表現型をもつ集団は認められなかっ た.DN胸腺細胞は表現型においても機能的にも様々 亿異なった集団からなっており ${ }^{28)}$, 少なくともCD $3^{-}$と $\mathrm{CD} 3^{+}$の 2 つの゙ループに分けられる ${ }^{291}$. 前者より DP・SP，またおそらくは CD $3{ }^{+} \mathrm{DN}$ 胸 腺細胞が分化するものと考えられている. トラン スシェニックマウスのDN胸腺細胞の大半は Thy$1.1^{-} /$Thy-1.2 $2^{+} / \mathrm{CD} 3^{-}$である. このことは胸腺 細胞発生の初期において, 導入 Thy-1.1 は内在性 Thy-1.2 亿遅れて発現されることを示唆している. DP胸腺細胞の殆どが Thy-1.1+なので, 殆どの胸 腺細胞での Thy-1.1 発現のプロセスが CD 4 ・C D 8 の発現と同時に起こっているようである.し かし, 少数の Thy -1.1 陰性の CD $8^{+} / \mathrm{CD} 44^{-} / \mathrm{CD}$ $3^{-}$胸腺細胞が存在するというととも注目に価す る(Fig.-4b).乙のような少数の細胞の起源は今 のところ不明である.

$\mathrm{CD} 3^{+} \mathrm{DN}$ 胸腺細胞は, $\mathrm{CD} 3{ }^{+} \mathrm{SP}$ 細胞への分 化系統とは異なる別個の亜集団である可能性が考 えられている30131!. それらの細胞は TCR に対する 抗体による刺激に対して反応性を有するので, 機 能的に成熟した細胞であると考えられている ${ }^{30}$. 全ての CD $3^{+}$DN 胸腺細胞は Thy- $1.1^{-} /$Thy$1.2^{+}$で, 表現型においては成熟した末梢T細胞型で あった. 一方, 今回の検索で Thy-1.1 $1^{+} /$Thy- $1.2^{+}$ の $\mathrm{CD} 3^{+} \mathrm{DN}$ 胸腺細胞の存在は見られなかった。 この点は, CD $3{ }^{+} \mathrm{SP}$ 胸腺細胞に Thy- $1.1^{+} /$Thy$1.2^{+}$の亜集団が存在するととと明らかに対照的 であり，SP T細胞と成熟 DN T細胞との成熟過程 が異なるととを示すものと考えられる.

今回の研究から, Thy- $1.1^{+}$SP 胸腺細胞が末梢 
T細胞と比較してどのように機能的に異なってい るか, また Thy-1.1+, Thy-1.1-の 2 つのSP胸腺 細胞間で TCR のレパートリーに差異が認められ るかなどの課題が提出されたが, これらの点につ いては現在研究中である.

\section{まとめ}

マウスの Thy-1.1 遺伝子を導入したトランス シェニックマウスを生産し, 乙れらのマウスにお ける導入 Thy-1.1 の発現様式を調べ, 次のことが 明らかになった。

1. 導入 Thy-1.1 の発現は胸腺細胞には認められ たが, 未梢T細胞には認められなかった. 胸腺内に おいて内在性 Thy-1.2 は殆ど全ての胸腺細胞に 発現するが, 導入 Thy-1.1 の発現は胸腺細胞の約 88\%に限られていた。 このような Thy-1.1 のユニー クな発現は, 導入遺伝子に一定の cis-acting element を欠くためと考えられた。

2. 全ての $\mathrm{CD} 4{ }^{+} \mathrm{CD} 8{ }^{+} \mathrm{DP}$ 胸腺細胞は内在性 Thy-1.2 $2^{+}$であり, その殆どは導入 Thy-1.1 につ いても陽性であった。

3 . 殆ど全ての分化した $\mathrm{CD} 3^{+} / \mathrm{TCR} \alpha / \beta^{+}$の SP胸腺細胞には, 内在性 Thy-1.2 の発現はあった が, 導入 Thy-1.1 の発現に関しては陽性と陰性の 2 つのグループに分けられた. この両者間におい て TCR $\alpha / \beta$ の発現量に差は認められなかった. このととから, 胸腺内SP細胞中にも分化段階の異 なる細胞の存在することが示唆された。

4. DN胸腺細胞は, Thy-1.1 $1^{+} /$Thy $-1.2^{+} \cdot$ Thy-1.1 $/$ Thy- $1.2^{+} \cdot$ Thy- $1.1^{-} /$Thy- $1.2^{-}$の $3 \supset の$ subpopulation に分けられた. CD $3^{+} \mathrm{DN}$ 胸腺細 胞の大部分は末梢T細胞のThy-1.1-/Thy-1.2 ${ }^{+}$の 表現型を示し, SP細胞にみられたThy-1.1+ Thy-1.2+ の表現型をもつ CD $3^{+}$細胞は認められ なかった.このととから, SP胸腺細胞と CD $3{ }^{+} \mathrm{D}$ $\mathrm{N}$ 細胞とは成熟過程を異にすると考えられた。

以上のように, 今回われわれが生産した Thy-1.1 トランスシェニックマウスは, 現在まで不明で あった CD $3^{+}$胸腺細胞の最終成熟過程を研究
する上で有用なモデルであると考えられた。

謝辞 稿を終えるにあたり, 研究の機会をお与え下さり, ご校閲を賜った順天堂大学産婦人科学教室高田道夫教授 に心より感謝いたします.また，直接で指導とで校閲を 賜った順天堂大学病理学第二教室白井俊一教授に深甚な る謝意を表します. 併せて, 本研究にで助言・で協力頂 いた産婦人科学教室・病理学第二教室の方々に心からお 礼申し上げます。

\section{文献}

1 ) Campbell, D.G., Gagnon, J., Reid, K.B.M., et al .: Rat brain Thy-1 glycoprotein: The aminoacid sequence, disulphide bonds and unusual hydrophobic region. Biochem. J., 195 : 15 30, 1981

2 ) Williams, A.F., Gagnon, J.: Neuronal cell Thy-1 glycoprotein : homology with immunoglobulin. Science, $216: 696 \sim 703,1982$

$3)$ Reif, A.E., Allen, J.M. V.: The AKR thymic antigen and its distribution in leukemias and nervous tissues. J. Exp. Med., 120: 413 433, 1964

4 ) Marshak-Rothstein, A., Fink, P., Gridley, T., et al.: Properties and applications of monoclonal antibodies directed against determinants of the Thy-1 locus. J. Immunol., 122 : 2491 2497, 1979

5 ) Raff, M.C.: Surface antigenic markers for distinguishing $\mathrm{T}$ and $\mathrm{B}$ lymphocytes in mice. Transplant Rev., $6: 52 \sim 80,1971$

6 ) Reif, A.E., Allen, J.M.W.: Mouse nervous tissue isoantigens. Nature, $209: 523,1971$

7 ) Morris, R.: Thy-1 in developing nervous tissue. Dev. Neurosci., $7: 133 \sim 160,1985$

8 ) Dalchau, R., Fabre, J.W.: Identification and unusual tissue distribution of the canine and human homologues of Thy-1 $(\theta)$. J. Exp. Med., 149 : 576 591, 1979

9 ) Seeger, R.C., Danon, Y.L., Rayner, S. A., et $a l .:$ Definition of a Thy-1 determinant on human neuroblastoma, glioma, sarcoma and teratoma cells with a monoclonal antibody. J. Im- 
munol., $128:$ 983 989, 1982

10) Retting, W. J., Dracopoli, N. C. , Chesa, P. G. , et al.: Role of human chromosome 11 in determining surface antigenic phenotype of normal and malignant cells. Somatic cell genetic analysis of eight antigens, including putative human Thy-1. J. Exp. Med., 162 : 1603 1619, 1985

11) Acton, R.T., Morris, R.J., Williams, A.F.: Estimation of the amount and tissue distribution of rat Thy-1. 1 antigen. Eur. J. Immunol., $4: 598 \sim 602,1974$

12) Ritter, M. A., Gordon, L.K., Goldschneider, I. : Distribution and identity of Thy-1-bearing cells during ontogeny in rat hemopoietic and lymphoid tissues. J. Immunol., 121 : 2463 2471,1978

13) Gordon, J. W. , Chesa, P. G., Nishimura, H., et al.: Regulation of Thy-1 gene expression in transgenic mice. Cell, 50:445 452, 1987

14) Chang, H.C., Seki, T., Moriuchi, T., et al .: Isolation and characterization of mouse Thy-1 genomic clones. Proc. Natl. Acad. Sci. USA, $82: 3819 \sim 3823,1985$

15) Giguere, V., Isobe, K.I., Grosveld, F. : Structure of the murine Thy-1 gene. EMBO J., 4 : $2017 \sim 2024,1985$

16) Ralph, P.: Retention of lymphocyte characteristics by myelomas and $\theta^{+}$lymphomas : Sensitivity to cortisol and phyto-hemagglutinin. J. Immunol. , 110 : 1470 1480, 1973

17) Leo, O., Foo, M., Sachs, D. H., et al. : Identification of a monoclonal antibody specific for a murine T 3 polypeptide. Proc. Natl. Acad. Sci. USA., $84:$ 1374 1378, 1987

18) Bluestone, J. A., Pardoll, D., Sharrow, S.O., et al.: Characterization of murine thymocytes with CD 3 -associated T-cell receptor structures. Nature, $326: 82 \sim 84,1987$

19) Kubo, R. T., Born, W., Kappler, J. W., et al. : Characterization of monoclonal antibody which detects all murine $\alpha \beta$ T cell receptors. J. Immunol., $142: 2736 \sim 2742,1989$

$20)$ Itohara, S., Nakanishi, N., Kanagawa, O., et al.: Monoclonal antibodies specific to native murine T-cell receptor $\gamma \delta$ : Analysis of $\gamma \delta$ $\mathrm{T}$ cell during thymic ontogeny and in peripheral lymphoid organs. Proc. Natl. Acad. Sci. USA., 86 : 5094 5098, 1989

21) Vartdal, F., Kvalheim, G., Lea, T.E., et al .: Depletion of $\mathrm{T}$ lymphocytes from human bone marrow. Use of magnetic monosized polymer microspheres coated with $\mathrm{T}$ lymphocyte-specific monoclonal antibodies. Transplantation, 43 : $366 \sim 371,1987$

22) Isobe, K. I. , Kollias, G., Kolsto, A. B., et al. : $T$ cell independent $T h y-1$ alloantibody response with the use of transgenic mice. J. Immunol ., $137: 2089 \sim 2092,1986$

23 ) Kollias, G., Spanopoulou, E., Grosveld, F., et al .: Differential regulation of a Thy-1 gene in transgenic mice. Proc. Natl. Acad. Sci. USA., 84 : 1492 1496, 1987

24) Vidal, M., Morris, R., Grosveld, F., et al .: Tissue-specific control elements of the Thy-1 gene. EMBO J., $9: 833 \sim 840,1990$

25) Krimpenfort, P., de Jong, R., Uematsu, Y., et al.: Transcription of $\mathrm{T}$ cell receptor $\beta$-chain genes is controlled by a downstream regulatory element. EMBO J., $7: 745 \sim 750,1988$

26 ) Serfling, E., Barthelmäs, R., Pfeuffer, I., et al .: Ubiquitous and lymphocyte specific factors are involved in the induction of the mouse interleukin 2 gene in $\mathrm{T}$ lymphocytes. EMBO J ., $8: 465 \sim 473,1989$

$27)$ Hashimoto, Y . : T cell receptor $\beta$ gene has two downstream DNase I hypersensitive regions : Possible mechanisms of tissue and stagespecific gene regulation. J. Exp. Med., 169 : $2097 \sim 2107,1989$

28 ) Fowlkes, B.J., Pardoll, D.M.: Molecular and cellular events of $T$ cell development. In : Dixon, F.J., eds. Advances in Immunology., $44: 207 \sim 264$, Academic Press, San Diego, 1989

29) Shirai, T., Abe, M., Yagita, H., et al.: The expanded populations of $\mathrm{CD} 4^{-} \mathrm{CD} 8^{-} \mathrm{T}$ cell receptor $\alpha / \beta^{+} \mathrm{T}$ cells associated with the $l p r$ 
and gld mutations are $\mathrm{CD} 2^{-}$. J. Immunol., 144 : 3756 3761, 1990

30) Fowlkes, B. J., Kruisbeek, A.M., Ton-That, H., et al.: A novel population of $\mathrm{T}$ cell receptor $\alpha / \beta$-bearing thymocytes which predominantly expresses a single $\mathrm{V} \beta$ gene family. Natu- re, $329: 251 \sim 254,1987$

31) Ceredig, R., Lynch, F., New man, P. : Phenotypic properties, interleukin 2 production, and developmental origin of a "mature" subpopulation of Lyt- $2^{-}$L3T $4^{-}$mouse thymocytes. Proc. Natl. Acad. Sci. USA., $84: 8578 \sim 8582,1987$

Original Paper

\section{Summary}

\section{Expression pattern of Thy-1.1 antigen in transgenic mice}

We established a line of transgenic mice carrying the exogenous mouse Thy- 1.1 gene ( 8.2 $\mathrm{kb}$ EcoRI genomic DNA fragment). In these mice, Thy-1.1 was expressd on thymocytes but not on peripheral $\mathrm{T}$ cells, presumably due to the lack of cis-acting elements on the microinjected genomic DNA. In the thymus, the transgenic Thy-1.1 was expressed on most of the $\mathrm{CD} 3 / \mathrm{TCR}^{-}$thymocytes. However, the $\mathrm{CD} 4{ }^{+}$or $\mathrm{CD} 8^{+}$single positive (SP) thymocytes consisted of Thy $-1.1^{+}$and Thy $-1.1^{-}$subsets, the former considered to be at a premature stage of terminal $\mathrm{T}$ cell differentiation. There was no difference in the amount of CD $3 /$ TCR complexes expressed on the two SP thymocyte subsets. In the double negative (DN) thymocytes, all the $\mathrm{CD}^{+} / \mathrm{TCR}^{+}$cells were Thy-1.1- $1^{-}$These results suggest that the maturation process of $\mathrm{CD}^{+}$DN thymocytes differs from that of SP thymocytes. The distribution of the Thy $-1.1^{+}$population among the CD $3^{+}$thymocytes suggests that the transgenic Thy-1.1 gene expression can serve as a useful marker to examine the terminal maturation processes of $\mathrm{CD} 3^{+}$thymocytes.

Key words : Thy-1.1, thymocytes maturation, transgenic mouse

$$
\begin{gathered}
\text { Masanori AWAJI, M. D. * } 1 \text { ) JU-ICHI SAITOH, M. D. * } 1 \text { ) } \\
\text { Shingo NOZAWA, M. D. , }{ }^{* 2)} \text { MASAAKI ABE, Ph.D. }{ }^{*} \text { ) } \\
\text { \& Hiroy UKi NISHIMURA, Ph. D. *2) }
\end{gathered}
$$

* 1 ) Department of Obstetrics and Gynecology, Juntendo University School of Medicine, Tokyo, Japan

* 2 ) Department of Pathology ( II ), Juntendo University School of Medicine, Tokyo, Japan 